\title{
Modern Principles of Financial Services Markets Regulation as a Response to the Financial and Economic Crisis of 2008
}

Valitov S.M.

Nigmetzyanov A.A.

Kazan Federal University, Institute of Management, Economics and Finance, Kazan, 420008, Russia

\section{Doi:10.5901/mjss.2014.v5n24p285}

Abstract

The financial and economic crisis of 2008 revealed lack of tools and inefficiency of methods used by regulators of leading states to predict and prevent crisis of global proportions. In this regard, national and supranational regulators are trying to introduce new principles for regulation of financial services markets, based on the philosophy of macro-prudential regulation. The paper presents a comparative analysis of institutions and methods of regulation in the USA, UK and European Union. The authors critically analyze the effectiveness of new models of regulators, questioning the benefits of new ones in comparison with previous. They emphasize the necessity to reform not only institutional structure of regulators but methodology of their activities too, as well as, the absence of universal prescription of reforms, coming to conclusion, that each country must choose its own, based on their legal traditions, regulatory system.

Keywords: financial services markets, regulator of securities, qualified investors, financial regulation, principles of financial regulation, systemic risk, prudential rules, macro-prudential regulation, models of macro-prudential regulation, micro-prudential regulation.

\section{Introduction}

Development of modern principles of regulation arising in the financial services markets was influenced by the complex global economic process of the twentieth century. The impetus for the formation of the legislation on securities was the financial crisis of 1929. For instance, as said Bernanke: 'To understand the Great Depression is the Holy Grail of macroeconomics.'[1] Three legislative acts as a response to the financial crisis of 1929-1934 reformed the financial market in the USA. The principles underpinning these acts have provided formation of stable financial market and influenced on the development of European legislation [2]. First of all, it was the Glass-Steagal Act of 1933, which separated investment and commercial banking. Secondly, it was the Securities Act of 1933, which regulated the issuance of new securities. Thirdly, it was the Securities and Exchange Act of 1934, which regulated issued securities; for instance, prohibition of insider trading [3]; and established the Securities and Exchange Commission (SEC). In turn, the SEC is a special state body responsible for the securities market and subordinated directly to the President of the USA. This Commission established the procedure of accessing to the conduct of professional activities on the securities market, carrying out the control over the activities of brokers, dealers, asset managers and other professional members providing services to third parties. Access to professional services could be obtained on the basis of the license or through membership in self-regulatory organizations or stock exchanges. In addition, the SEC was responsible for registration of securities, primarily stocks and bonds, which had to be sold to the public. In other words, the American 'post-Great Depression' legislation created the framework of micro-prudential regulation, which was progressive and efficient until the 2008 financial crisis.

\section{Development of Modern Principles of Financial Regulation}

Despite some criticism of establishing a regulator of securities from proponents of 'light touch' regulation [4], these principles have defined the framework of state regulation of the financial market. Moreover, it can be stated that these principles are almost universal and found reflection in the EU directives and national legal acts of the EU Member States [5]. However, by setting stringent requirement in respect of the procedure of issue of securities held for proposals to public, the legislative may provide for a more liberal regulatory regime in respect of other financial instruments. For instance, it may be securities held for offer to professional participants of the financial market [6]. These persons usually 
referred to as 'qualified investors' that include professional participants of the securities market, such as asset management companies of investment funds or credit organizations. It is assumed that these organizations have ability to properly and adequately assess the risks associated with investments in instruments that are not registered in the authorized state body. Moreover, the state establishing special requirements for professional securities market participants also has the ability to keep them from being too risky, thereby protecting their clients - investors. After all, violations of investors' rights undermine the credibility of the national financial market, destabilizing it. This approach determines the ratio of civil law norms and special administrative norms regulating legal relations that arise in financial markets. Hence, this balance of self-regulation or decentralization and state or centralized regulation depends on the legal traditions and understanding of the nature of law. For instance, in civil law countries, it is more centralized regulation. In contrast, in common law countries, it is more decentralized regulation. However, the last financial debacle shifted regulation towards more centralization.

Compliance with requirements relating to the securities and financial instruments held for qualified investors has become a worldwide practice. Undesirable effects occur not only for purchasers of securities but primarily for professional market participants. As noted in the report of the group investigating the causes of the 2008 crisis, regulation should become more intelligent and not allowing to go on about professional investors [7]. In the world practice, there is a prohibition for professional market participants to offer financial instruments to non-qualified investors. In the USA the rules of issue and distribution of securities intended for qualified investors were established under the Securities Act of 1933 rule 144-A [8],[9],[10]. Meanwhile, in the UK self-regulation prevailed until 1987, when Financial Services Act of 1986 came into force [11]. Such regulation exists in the EU too. In particular, the distribution of the securities by means of offering them to the qualified investors is carried out by means of direct indication that the paper should fulfill the requirements of EC Directive 2003/71/EC [12] establishing the compulsory registration of prospectuses of securities. The prospectus of the relevant type of securities is prohibited to offer this security to unqualified investors. However, the current financial market with modern policies of complicated financial instruments and massive and interconnected financial institutions demands a new level of regulation, a macro level.

Modern system of macro-prudential regulation. Current system of financial regulation is unable to provide managed volatility of the financial market. Consequently, achieving relative stability of functioning of financial institutions is a very relevant question. Events at the world financial markets will make one to rethink the basic concepts and hypotheses of the system of financial regulation [13], particularly issues related to systemic risk posed by 'too big to fail' financial institutions. Moreover, modern financial and economic markets are characterized as a global complex open system. In other words, when a fault occurs in one of the elements of this system, problems can spread throughout the system and may lead to stagnation of the system as a whole.

\subsection{Models of macro-prudential supervision}

To keep control over the development of world and national financial systems and prevent further systemic crises, leading world states focused on macro-prudential regulation and supervision. Simplifying, it is 'to help prevent the build-up of bubbles' [14]. For instance, to provide macro-prudential regulation the USA, the UK and the EU created new systemic risk agencies: the Financial Stability Oversight Board (FSOC), the Financial Policy Committee (FPC) and the European Systemic Risk Board (ESRB) respectively. Thus, as a response to financial crisis the leading states changed rules and institutional structures of financial regulation [15]. In addition, it would be better if these high-level financial supervisors were compatible and collaborated to each other [16]. These decisions are based on the already proved its fallacy opinion of the leading countries that to deal with the crisis is enough to have a regulatory system.

Modification of the system of macro-prudential analysis is expressed in the rejection of the model of a 'single regulator', which has proven inability to regulate the threats of the market, because of lack attention to the 'issues of systemic risk, systemically significant firms and systemic resilience' [17], in favor of 'twin peaks' model (for instance, the UK). This separation of functions enables greater concentration on particular management objectives. For instance, it can be management of systemic risk or protection of the consumers and investors rights separately. This innovation is aimed to reduce overlapping of functions and risk of competition targets inside the regulatory body. Thus, it can be expected increasing of the efficiency of response to emerging threats. However, the offered model may contribute to regulatory arbitrage between different sectors of the financial market.

In addition, it cannot be excluded that risks will concentrate in the less regulated sectors of economy. This fact is of particular importance because uncontrolled growth of risky assets of the least regulated financial operators in the USA is a result of active trade in the market of financial derivative instruments. Similarly, these uncontrolled derivatives became one of the causes of the last financial crunch, which spread to the entire global financial and economic system [18]. It is 
therefore pertinent to state that, in the world practice there is no a universal model of the macro-prudential system of regulation. It can be explained by different legal traditions and understanding of the nature of law. Thus, currently, each country seeks and accepts its own, sometimes different, approaches. These solutions are based on the adoption of international experience of the established legal and institutional system of the country.

\subsubsection{The USA model}

The USA, in accordance with the Dodd-Frank Act [19], holds the most radical reforming of financial regulation since the Great Depression [20]. This is understandable, since the scale of the recent crisis comparable with the crisis of the first third of the twentieth century. The only difference is in the nature of crises. The recent one is a banking or credit crisis, while, the Great Depression was a stock-market crisis [21]. In connection with that, the Dodd-Frank Act requires changes in the current institutional structure for regulation of financial system by more centralization [22]. It provides a system of supervision and monitoring systemic risks to 're-impose controls' [23]. The main aim of the Act is 'To promote the financial stability of the United States..., to end 'too big to fail' [24]. It moves in the direction of strengthening of control over systemically important companies. For instance, the Act addresses special leverage ratios on SIFIs [25]. In addition, regulators get power for the rehabilitation and liquidation of problematic financial companies, which can be risky for the financial stability of the USA. It is particular important including in the scope of regulation non-banking financial institutions and other companies which are the parts of the holding and, consequently, can bear risks for the whole financial system.

However, in spite of having progressive ideas, the Dodd-Frank Act was criticized for being lengthy and complicated [26]. Similarly, Baber states that the Dodd-Frank Act 'have been finalized too quickly, without a full review of the potential implications within the financial sector' [27]. Moreover, currently, it is quite difficult to state the full compliance of new legislative initiatives to the goals of reforms. For instance, the Act does not contain instruments of size decreasing of 'too big to fail' institutions [28]. Consequently, in the case of crisis the government will bail-out big banks again [29],[30]. This policy laid the groundwork for future crises by reducing financial discipline and formation expectations of mandatory SIFIs support [31]. As a result, the problem of 'too big to fail' is unresolved and the probability of potential financial crises is not minimized.

\subsubsection{The UK model}

In the UK, the regulatory reforms lead to building more centralized system of regulation. The policy of transition to the new structure of macro-prudential regulation is based on the ideas of accounting of individual behavior for regulation [32],[33]. The tripartite system of regulation: The Financial Services Authority (FSA), Bank of England, HM Treasury, is replaced by a new structure, consisting of: Financial Policy Committee (FPC), Prudential Regulation Authority (PRA), Financial Conduct Authority (FCA). In comparison with the previous ones, the credentials of new regulators are broader. For instance, FPC, a committee of the Court of the Bank of England, is responsible for protection the stability of the financial system in general, or macro-prudential regulation [34]. The activities of the PRA, a subsidiary of the Bank of England, aim at reducing the risks of the financial system by ensuring safe and reliable functioning of the regulated companies, or micro-prudential regulation [35]. FCA, independent regulator, is responsible for the protection and improvement of confidence in the UK financial system through the control over the market infrastructure and regulation of the conduct of agents and companies on banking, investment and insurance markets, which are not subject to regulation under PRA, and following a new trend in regulation is going to apply more interventionist approach in comparison with the FSA, which used more preventive approach [36].

However, Hudson [37] reasonably criticizes the new tripartite system for great opportunity of overlapping functions of micro-prudential regulation and conduct of business. Moreover, during the last financial crisis all former three bodies claimed each others for not predicting and preventing of the crisis. Currently, the conception of the regulation has not changed [38]. Thus, the rationale of the new system is quite unclear. In addition, there is doubt about the profitability of such significant transformations. In contrast, the previous system was relatively developed, but the new one will have to be tested; and it is unknown how it will resist a stressful situation [39],[40]. Thus, it seems that new system solely increases the level of bureaucracy, but methods of regulation have not been changed.

\subsubsection{The European Union model}

On 22 September 2010, the European Parliament approved a plan of reforming of the EU financial regulation system. This reform is aimed at ensuring the sustainability and stability of the financial system through the improvement of the 
institutional structure of regulation, elimination of problems of fragmentation of individual risk analyses at the national levels, development of the system for early detection and prevention of the emergence of systemic risks. However, in spite of being relatively simple, a European model is more practical in comparison with mentioned above systems. Also, like the previous models, it focuses on expanding of macro-prudential supervision on the entire financial system. For this reason, in December 2010 it was created a new independent body, European Systemic Risk Board (ESRB) [41], which is responsible for macro-prudential supervision of the whole EU financial system. Moreover, ESRB coordinates the activities of the three main European Supervisory Authorities (ESAs). That is European Securities and Markets Authority (ESMA) [42], European Banking Authority (EBA) [43], European Insurance and Pensions Authority (EIOPA) [44].

The main purpose of this institute is to prevent or mitigate systemic risks in order to ensure financial stability in the EU or at least to limit the distribution of the financial turmoil in the region. First practical results of the ESRB work are the development of methodological bases of the institute's work, providing monitoring and stress tests of the European markets with the aim of identifying, prohibiting and preventing potential systemic risks and the development on their bases programs of measures of risks elimination. Unlike the policies implemented in the USA and UK models of hard regulation, the EU applies a policy of soft law. In other words, in case of detection of risks in the financial system regulator uses tools such as warnings and recommendations. In comparison to the UK, the EU is more actively involved in the regulation of hedge funds, private equity funds, rating agencies and over-the-counter derivatives market [45]. This is explainable by the fact that it is impossible to overestimate the negative contribution of these institutions in the development of the last financial crisis, for example the impact of activities of such SIFI, as AIG [46]. In comparison with the Dodd-Frank Act, Baber underlines a more 'sincere and comprehensive approach to contain the consequences of the collapse and to establish an effective and fair supervisory regime in the future' [47].

However, the ECRB is only theoretically independent body. Practically, it is embedded into European Central Bank (ECB), which could neither prevent no predict the last financial crunch [48]. For this reason, it seems that close relationship of these bodies will not be productive in preventing future financial crises. Secondly, in spite of having advantages of implementing the soft law, in case of emergency it will be rather difficult to force national authority to comply with ECRB and will become less legal and more political process [49]. Moreover, a complex system of coordination and policy making in the EU framework is the reason for the lack of responsiveness to perceived threats [50]. This problem is not new and it was tried to cope since 1963, when Segre in his report underlined the importance of integration of the European financial markets.

\subsubsection{Background of the EU financial regulation}

\subsubsection{Segre report}

The main purpose of the Segre Committee's study was to identify the factors necessary for the development of the European financial market [51]. The report clearly drew emphasis on the importance of integration of the European financial market [52]. In order to implement the proposals of the Segre Committee on trade in securities and on the legal basis of the Rome Treaty, from 1972 to 1982, three directives were adopted: Directive 79/279/EEC [53], Directive 80/390/EEC [54] and Directive 82/121/EEC [55]. Later in 1985 the White Paper from the Commission to the European Council, it was noted that to achieve integration there is a need of liberalization of financial activity [56]. However, the Committee stated that regulation should be in the national jurisdictions; and, this legal separation would help to increase liquidity in financial market [57]. In other words, 'the European Commission committed itself to the concept of minimum harmonization.' [58] In 1988, due to the lack of regulation at the national level, Directive 88/627/EEC was adopted [59]. The main purpose of this Directive was to protect the investor through the provision of adequate information. Further, in 1989, Directive 89/298/EEC aimed to ensure availability of information on securities [60]. Then, to prevent insider dealing Directive 89/592/EEC was adopted [61]. Finally, to protect investor, Directive 93/22/EEC introduced the concept of 'prudential rules' [62]. These rules require the keeping of records of transactions and investors' notification. In 1999 in order to further integration of the European market the Commission in its Financial Services Action Plan (FSAP) [63] proposed to introduce the single European currency [64], as well as, to organize a securities committee [65].

\subsubsection{Lamfalussy process}

On 9 November 2000, the Committee, led by Lamfalussy, published an initial report [66] which criticized the slowness of the legislative process [67]. In particular, it was pointed on the significant difference of the EU Members' rules [68]. On 15 February 2001, the Committee published a final report [69] which outlined the measures needed to expedite the 
legislative process [70],[71]. These measures were called Lamfalussy process and consisted of four-level [72] system [73]. First, it is development of framework directives. Second, it is technical execution of these directives. For this reason, and to perform advisory functions a Committee of European Securities Regulators (CESR) [74] was organized. In addition, the CESR was responsible for improving the collaboration of the national supervisory bodies. Later, in order to meet modern principles of regulation, in 2003-2004, the Committee adopted four directives: the Market Abuse Directive (MAD, 2003), the Prospectus Directive (PD, 2003), the Markets in Financial Instruments Directive (MiFID, 2004) and the Transparency Directive (TD, 2004), which are currently the legal basis of European capital markets. Directive MAD 2003/6/EC [75] was adopted to prevent manipulation and insider dealing. Directive PD 2003/71/EC [76] regulates the requirements for the prospectus necessary for the issuance of securities. Directive 2004/39/EC [77] (MiFID) establishes framework for market organization and prudential rules for investment firms. Directive 2004/109/EC [78] (TD) is devoted to the issues of coordination of the transparency requirements of issuer information. Further, on 30 April 2004, to harmonize European takeover legislation, Directive 2004/25/EC [79] (TOD) was adopted. In 2005, the Commission proposed in its Green Paper [80] (May, 2005) and later confirmed in White Paper [81] (December, 2005) the economic profitability principle of legislative and enforcement processes.

\subsubsection{Post-crisis development}

\subsubsection{De Larosier report}

The last financial crisis of 2008-2009 revealed the necessity of preventing systemic risks committed by failure of large financial institutions which used to be reputed 'too big to fail'. Thus, this crisis showed the lack of global regulation and international cooperation of national authorities to diminish systemic risk and to terminate 'too big to fail' problem. In response to this situation, on 29th February 2009, the Committee under Jacques de Larosier chairmanship published a report [82] in which measures necessary to maintain financial stability at the global and European levels were suggested. In Europe, it was proposed to create a pan-European body that would coordinate activity of national supervisors. In turn, national regulators would execute the main obligation of direct supervision in their states. However, the UK government expressed disagreement against establishing of banking supervision body at the EU level [83]. Nevertheless, following the de Larosiere recommendations, on 23 September 2009, the Commission issued legislative measures to identify and prevent the systemic crisis in whole Europe ('macro-prudential supervision') and measures to update the regulation of individual market participants ('micro-prudential supervision') [84]. Thus, in 2010 a European System of Financial Supervision was organized. Functions of this organization were allocated among three separate bodies: the European Securities and Market Authority [85], the European Banking Authority (EBA) [86], the European Insurance and Occupational Pensions Authority (EIOPA) [87].

Before the crisis, the Commission did not planning any measures for regulation of activities of credit rating agencies and financial analysts, the requirements to the offer documents to purchase and the required minimum capital of market participants [88]. However, the crisis brought its corrections in relation to these matters. In particular, the issue of regulation of rating agencies raised in April 2002. Nevertheless, in April 2006 the Commission decided that there was no need of changing regulations of these agencies. The International Organization of Securities Commissions (IOSCO) deemed that self-regulation is the most suitable for rating agencies. However, the crisis showed that uncontrolled rating agencies played their negative role in wrong assessment of credit risks. Due to significance of rating agencies in global securities and banking markets, information of which were used by financial institutions for calculating risks in their investment activity, the European community realized the need of changing of credit ratings principles on the basis of integrity, transparency, responsibility and good governance in order to insure that agencies operate independently, objectively and produce reliable information [89].

For these reasons, to introduce prudential rules for rating agencies and to submit them to supervision, on 16 September 2009 the European Parliament and the Council adopted Regulation (EC) No. 1060/2009 on credit rating agencies. In subsequent years, with the aim of preventing financial crises and promoting financial stability, the Commission constantly proposes measures to update this Regulation. Based on these proposals, the Regulation shifts to the direction of more centralization of supervision at the European level in the ESMA competence and ensuring more transparency of credit rating agencies activities [90], of introducing of civil liability for incorrect information provided and more tough measures for discloser of these agencies [91]. In the last amendment, Regulation (EU) No.462/2013 [92], taking into account bias position of rating agencies towards big financial institutions, the subject matter was changed by adding the concept the avoidance of conflicts of interest [93], in other words the conflicts between consumer and SIFI. 


\subsubsection{Modernization of framework directives}

The 2008-2009 financial crisis exposed weaknesses in four framework Directives: Market Abuse Directive (MAD), Prospectus Directive (PD), The Markets in Financial Instruments Directive (MiFID) and Transparency Directive (TD). These acts adopted in 2003-2004 in other financial and economical circumstances were not adjusted to new conditions. Particularly, these acts had insufficient regulatory ability, undeveloped investigative capability and sanctioning powers. Moreover, regulations on national level were not enough harmonized. In connection with the foregoing, the Commission, consulted with CESR and the European Securities Markets Expert Group (ESME), proposed measures to modernize framework Directives. Later, in 2010, the European Parliament adopted Directive 2010/73/EU [94] with strong intention to improve investors' protection. Further, as MAD amendment [95], the Commission proposed to introduce administrative and criminal responsibility for committing insider dealing and market manipulation [96]. Nevertheless, the existing MAD, in the case of adopting by Parliament and the Council, will be replaced not earlier than 2015.

The next proposal [97] is related to TD and aimed to reduce administrative barriers for small and medium-sized financial institutions, as well as harmonization of the notification mode of large financial groups. However, practically, this proposal can be implemented not earlier than 2014. Also, the Commission proposed to update MiFID 2004/39/EC [98]. The main emphasis is made on insufficient regulation of the derivatives circulation, which in turn contributed to the development of the recent financial crisis. The financial meltdown has also highlighted the danger to the stability of the financial system of short sales. In this regard, to reduce systemic risk by increasing transparency, the Commission adopted Regulation No.236/2012 [99]. Further, taking into account that derivatives, especially OTC derivatives, also contributed to the 'swelling' of the financial 'bubble', the Commission adopted Regulation 648/2012 [100]. This Regulation demands stricter accounting of derivatives and more transparent to derivatives turnover.

\section{Conclusion}

Conclusively, setting down strict requirements in respect of professional participants and in relation to the procedure of conducting their operations in the financial markets, the state tries to ensure stable development of the national market. This issue is again in agenda, because the global financial crisis that began in 2008 has demonstrated that it is uncontrollable and reckless actions of market participants that led to severe economic consequences of global level. For this reason, strengthening of state regulation became imperative. However, it means not only increasing its scope, the number of rules or prohibitions and restrictions; but, the transformation of the state regulation mechanism from microprudential to macro-prudential that would prevent mistakes and problems leading to the systemic crisis. It seems that established supervisory bodies will be able to contribute to identifying and mitigating systemic risk. However, the results will be known only after stress-testing of the new systems.

In addition, it is worth to remember that the financial world is developing and can present new challenges. That is why new supervisory bodies should be flexible and capable to predict changes in the financial world. Moreover, the effectiveness of regulation depends primarily not on the degree of centralization or self-regulation, but mostly on philosophy of macro-prudential analysis and adopted on this basis administrative decision, that is the construction of the so-called "smart regulation". Such regulation should take into account the new systemic characteristics of financial markets and the major players of this market SIFIs. However, SIFIs are not only conventional banks, but also institutions engaged in banking activities, 'shadow banks', contributing to the growth in the number and severity of systemic crises in the economy and lead the modern global financial system into chaos and uncertainty. Thus, foregoing factors influence on the choice of regulatory system by national regulators and development of modern principles of regulation.

\section{References}

B.Bernanke, Essays on the Great Depression (Princeton 2000) 5

F.Spirgi, 'The Extraterritorial Application of the antifraud provisions of the Securities Exchange Act of 1934' (1989) 7 International Business Law Journal 837

J.M.Naylor, 'The use of criminal sanctions by UK and US authorities for insider trading: how can the two systems learn from each other' (1990) 11(3) Company Law 53

R.Bosworth-Davies, 'The SEC: An Examination of its Structure, Powers and Procedures' (1993) 2(1) Journal of Financial Regulation and Compliance 31

G.Thieffry, 'Towards a European Securities Commission' (1999) 1(7) Journal of International Financial Markets 300

N.G.Semilutina, 'The problem of correlation of civil and special legislation on financial services market (on the example of the federal law 'On investment partnership') (2012)7 Journal of Russian Law, LRS 'Garant' 
The Warwick Commission on International Financial Reform: In Praise of Unlevel Playing Fields. <http://www2.warwick.ac.uk /research/warwickcommission> accessed 5 July 2013

M.G.Capatides, 'Proposal Rule 144 A and related concerns' (1989) 4(2) Journal of International Banking Law 81

G.M.Reiter, 'Rule 144 A and resales of US privately-placed securities' (1990) 5(7) Journal of International Banking Law 276;

W.R.McLucas, Protection from international fraud-legal and enforcement developments: Part 2' (1993) 14(1) Company Lawyer 9

G.Baber, 'A critical examination of the legislative response in banking and financial regulation to issues related to misconduct in the context of the crisis of 2007-2009' (2013) 20(2) Journal of Financial Crime 237

Council Directive 2003/71/EC of the European Parliament and of the Council of 4 November 2003 on the prospectus to be published when securities are offered to the public or admitted to trading and amending Directive 2001/34/EC; OJ 2003 L345/64.

J.Stiglitz, 'The Lessons Of The North Atlantic Crisis For Economic Theory And Policy', Guardian (10.05.2013)

A. Haldane, 'In favour of macro-prudential regulation' (September 2012) 25(9) Risk 78-80,78

E.Ferran, N.Molney, J.G.Hill, Jr.Coffee, Jr.C.John, The regulatory aftermath of the global financial crisis (Cambridge 2012)

G.Baber, 'The European systemic risk board' (2011) 32(8) The Company Lawyer 225

E.Ferran, 'The Break-up of the Financial Services Authority' (2011) 31(3) Oxford Journal of Legal Studies 455-480, p.460

A.Hudson, The Law of Finance (Sweet and Maxwell, first edition, 2009) chapter 32

An Act to promote the financial stability of the USA by improving accountability and transparency in the financial system, to end 'too big to fail', to protect the American taxpayer by ending bailouts, to protect consumers from abusive financial services practices, and for other purposes (2010) US Congress, p.1

Davis-Polk, Summary of the Dodd-Frank Wall Street Reform and Consumer Protection Act, Passed

by the House of Representatives on June 30,2010 (July 2010) Washington: Davis-Polk.

Y.Cassis, Crises and Opportunities: The Shaping of Modern Finance (Oxford University Press 2011) p.152

Ch.L.Hauch, 'Dodd-Frank's Swap Clearing Requirements and Systemic Risk' (Winter 2013) 30(1) Yale Journal of Regulation 277

M.Keaney, 'From Hubris to Nemesis: Tackling US Decline' (09/2013) 11(3) Political Studies Review 358-368, ch. Finance Unleashed.

One Hundred Eleventh Congress of the United States of America (2010) 'Dodd-Frank Wall Street Reform and Consumer Protection Act' Washington, January 5th

A.H.Peterson, 'The Dodd-Frank Act' (October 2010) 76(10) Credit Union Magazine 30

N. Ferguson, 'The Darwinian Economy' (2012) (2) The Reith Lectures 2012, British Broadcasting Corporation <http://www.bbc.co.uk/ programmes/bo01jmxrx/features/transcript> accessed 29 July 2013

G.Baber, 'A critical examination of the legislative response in banking and financial regulation to issues related to misconduct in the context of the crisis of 2007-2009' (2013) 20(2) Journal of Financial Crime 237

L.C.da Silva, 'Don't run before you can walk: EU banking reform and the need for economic analysis' (June 2012) Oxera, Structural reform of EU banking 1

B.A.Rehm, 'An Alternative Plan to Fix TBTF: Lay Big Banks' Subsidy Bare' (7/25/2013) 178(174) American Banker 13

J.Stiglitz, 'Stiglitz: austerity won't work' Dublin Conference 2012, IBA Daily News (1 October 2012) 1,2

R.E.Prasch, 'The Dodd-Frank Act: Financial Reform or Business as Usual?' (2012) 46(2) Journal of Economic Issues 549

M.Cole, 'Financial Conduct Authority gives UK a chance to bolster regulation', The Telegraph (23.02.2011);

R.Grosse, 'Bank regulation, governance and the crisis: a behavioral finance view' (2012) 20(1) Journal of Financial Regulation and Compliance 4

HM Treasury, 'A new approach to financial regulation: the Blueprint for reform' (2011) Cm 8083 p.282 <http://www.hm-treasury.gov. uk/consult_finger_blueprint.htm> accessed 1 August 2013

HM Treasury, 'A new approach to financial regulation: the Blueprint for reform' (2011) Cm 8083 p.282 <http://www.hm-treasury.gov.uk /consult_finger_blueprint.htm> accessed 1 August 2013

M.Shoffman, 'FCA and PRA usher in new era of financial regulation', Financial Adviser (4 April 2013)

A.Hudson, 'Banking regulation and the ring-fence' (June 2013)107 Compliance Officer Bulletin 1-23

A.Hudson, 'Banking regulation and the ring-fence' (June 2013)107 Compliance Officer Bulletin 1-23

G.Baber, 'The new approach to financial regulation: a step into the unknown' (2011)32(9) Company Lawyer 276

G.Baber, 'The new approach to financial regulation: a step in the correct direction?' (2012)33(1) Company Lawyer 3

Regulation (EU) No 1092/2010 of the European Parliament and of the Council of 24 November 2010 on European Parliament and of the Council of 24 November 2010 on European Union Macro-prudential Oversight of the Financial System and Establishing a European Systemic Risk Board, OJ EU pp.L331/1-L331/11

Regulation (EU) No 1095/2010 of the European Parliament and of the Council of 24 November 2010 Establishing a European Supervisory Authority (European Securities and Markets Authority), OJ EU pp. L331/84-L331/119

Regulation (EU) No 1093/2010 of the European Parliament and of the Council of 24 November 2010 Establishing a European Supervisory Authority (European Banking Authority) OJ EU, pp. L331/12-331/47

Regulation (EU) No 1094/2010 of the European Parliament and the Council of 24 November 2010 Establishing a European Supervisory Authority (European Insurance and Pensions Authority) OJ EU, pp. L331/48-L331/83

I.MacNeil, 'The Trajectory of Regulation in the UK in the Wake of the Financial Crisis' (2010) 11 European Business Law Review 483526,503

E.F.Green, K.L.Mcllwain, J.T.Scott, 'A closer look at 'too big to fail': national and international approaches to addressing the risks of large, interconnected financial insstitutions' (2010) 5(2) Capital Markets Law Journal 117 
G.Baber, 'A critical examination of the legislative response in banking and banking and financial regulation to issues related to misconduct in the context of the crisis of 2007-2009' (2013) 20(2) Journal of Financial Crime 237

F.Costantino, 'Regulation of supervision on financial markets' (2012) 25(6/7) International Journal of Public Sector Management 437

F.Costantino, 'Regulation of supervision on financial markets' (2012) 25(6/7) International Journal of Public Sector Management 437

M.Goldstein, N.Veron, 'Too Big to Fail: The Transatlantic Debate' (January 2011) Peterson Institute for International Economics WP $11-2$

Commission, The Development of a European Capital Market, Report of a Group of experts appointed by the EEC Commission (Segre Report) (1966), p.11

Rudiger Veil, European Capital Markets Law (Oxford and Portland, Oregon 2013) 2

Council Directive 79/279/EEC of 5 March 1979 coordinating the conditions for the admission of securities to official stock exchanging listing, OJ LO66, 16 March 1979, p. 21-32; Legal base: EEC Treaty Articles 100, 54; Repealed by Directive 2001/34

Council Directive 80/390/EEC of 17 March 1980 coordinating the requirements for the drawing up, scrutiny and distribution of the listing particulars to be published for the admission of securities to official stock exchange listing, OJ L100, 17 April 1980, p.1-26; Legal base: EEC Treaty Articles 54, 100; Repealed by Directive 2001/34

Council Directive 82/121/EEC of 15 February 1982 on information to be published on a regular basis by companies the shares of which have been admitted to official stock exchange listing, OJ L048, 20 February 1982, p. 26-29;Legal base: EEC Treaty Articles 54, 100; Repealed by Directive 2001/34.

The Completing the Internal Market: White Paper from the Commission to the European Council (Milan, 28-29 June 1985) COM(85) 310 final, 14 June 1985, para. 101, 124

The Completing the Internal Market: White Paper from the Commission to the European Council (Milan, 28-29 June 1985) COM(85) 310 final, 14 June 1985, para 103, 107

T.M.J.Mollers, 'Sources of Law in European Securities Regulation - Effective Regulation, Soft Law and Legal Taxonomy from Lamfalussy to de Larosiere' (2010) 11 European Business Organization Law Review 379-407, 381

Council Directive 88/627/EEC of 12 December 1988 on the information to be published when a major holding in a listed company is acquired or disposed of, OJ L348, 17 December 1988, p.62-65; Legal base: EEC Treaty Articles 54, 149; Repealed by Directive 2001/34

Council Directive 89/298/EEC of 17 April 1989 coordinating the requirements for the drawing up, scrutiny and distribution of the prospectus to be published when transferrable securities are offered to the public, OJ L124, 5 May 1989, p.8-15; Legal base: EEC Treaty Articles 54, 149; Repealed by Directive 2003/71

Council Directive 89/592/EEC of 13 November 1989 coordinating regulations on insider dealing, OJ L334, 18 November 1989, p. 30-32; Legal base: EEC Treaty Articles 100A, 149; Repealed by Directive 2003/6

Council Directive 93/22/EEC of 10 May 1993 on investment services in the securities field, OJ L141, 11 June 1993, p. 27-46; Legal base: EEC Treaty Article 57; Article 12 repealed by Directive 1997/9; Repealed by Directive 2004/39

Communication from the Commission of 11 May 1999 - 'Implementing the framework for financial markets: action plan', COM (1999)

FSAP p.3 232 final (hereafter FSAP).

FSAP p.30

The Committee of Wise Men, Initial Report of the Committee of Wise Men on the Regulation of European Securities Markets (2000)

The Committee of Wise Men, Initial Report of the Committee of Wise Men on the Regulation of European Securities Markets (2000), p.18

V.Boland, 'Euro gives spur for updating: Regulation by Vincent Boland: IPO issuers face a range of standards and requirements in Europe. Meeting them is a costly and time-consuming exercise: [Surveys edition] Financial Times (London, 21 June 2001) 02

The Committee of Wise Men, Final Report of the Committee of Wise Men on the Regulation of European Securities Markets (2001)

The Committee of Wise Men, Final Report of the Committee of Wise Men on the Regulation of European Securities Markets (2001), p.27

S.Wolf, 'Recent developments in European Union securities law' (2002) 30(3) Denver Journal of International Law and Policy 292

G.Thieffry, 'Comment: European securities regulation' (May 2001) 20(5) International Financial Law Review 15

C.De Visscher, O.Maiscocq, F.Varon, 'The Lamfalussy Reform in the EU Securities Markets: Fiduciary Relationships, Policy Effectiveness and Balance of Power' (2008) 28(1) Journal of Public Policy 19

T.M.J.Mollers, 'Sources of Law in European Securities Regulation - Effective Regulation, Soft Law and Legal Taxotomy from Lamfalussy to de Larosiere' (2010) 11 European Business Organization Law Review 379, 383

Directive 2003/6/EC of the European Parliament and of the Council of 28 January 2003 on insider dealing and market manipulation (Market Abuse), OJ L096, 12 April 2003, p. 16-25

Directive 2003/71/EC of the European Parliament and of the Council of 4 November 2003 on the prospectus to be published when securities are offered to the public or admitted to trading and amending Directive 2001/34/EC, OJ L345, 31 December 2003, p.64-89

Directive 2004/39/EC of the European Parliament and of the Council of 21 April 2004 on markets in financial instruments amending Council Directives 85/611/EEC and 93/6/EEC and Directive 2000/12/EC of the European Parliament and of the Council and repealing Council Directive 93/22/EEC, OJ L145, 30 April 2004, p. 1-44

Directive 2004/109/EC of the European Parliament and of the Council of 15 December 2004 on the harmonization of transparency requirements in relation to information about issuers whose securities are admitted to trading on a regulated market and amending Directive 2001/34/EC, OJ L390, 31 December 2004, p.38-57 
Directive 2004/25/EC of the European Parliament and of the Council of 21 April 2004 on takeover bids, OJ L142, 30 April 2004, p.12-23 Commission, Green Paper on Financial Services Policy (2005-2010), 3 May 2005, COM(2005) 177 final

Commission, White Paper on Financial Services Policy (2005-2010), 1 December 2005, COM(2005) 629 final

The de Larosiere Group, 'The High-Level Group on Financial Supervisions in the EU' (2009) <http://ec.europa.eu/commission_barroso /president/pdf/statement_20090225_en.pdf> accessed 30 June 2013

Y.Cassis, Crises and Opportunities: The Shaping of Modern Finance (Oxford University Press 2011) p.130

Communication from the Commission on European financial supervision, 27 May 2009, COM(2009) 252 final

Regulation (EU) No 1095/2010 of the European Parliament and of the Council of 24 November 2010 Establishing a European Supervisory Authority (European Securities and Markets Authority), OJ EU pp. L331/84-L331/119

Regulation (EU) No 1093/2010 of the European Parliament and of the Council of 24 November 2010 Establishing a European Supervisory Authority (European Banking Authority) OJ EU, pp. L331/12-331/47

Regulation (EU) No 1094/2010 of the European Parliament and the Council of 24 November 2010 Establishing a European Supervisory Authority (European Insurance and Pensions Authority) OJ EU, pp. L331/48-L331/83

Commission, White Paper on Financial Services Policy (2005-2010), 1 December 2005, COM(2005) 629 final, p.14

Recital 1 Regulation (EC) No. 1060/2009 of the European Parliament and of the Council of 16 September 2009 on credit rating agencies

Regulation (EU) No. 513/2011 of the European Parliament and of the Council of 11 May 2011 amending Regulation (EC) No. 1060/2009 on credit rating agencies, OJ L145, 31 May 2011, p.30

Commission, Proposal for a Regulation of the European Parliament and of the Council amending Regulation (EC) No. 1060/2009 on credit rating agencies, $\mathrm{COM}(2011) 742 / 2$

Regulation (EU) No. 462/2013 of the European Parliament and of the Council of 21 May 2013 amending Regulation (EC) No. 1060/2009 on credit rating agencies, OJ L146, 31 May 2013, p.1

Article 1, Regulation (EU) No. 462/2013 of the European Parliament and of the Council of 21 May 2013 amending Regulation (EC) No. 1060/2009 on credit rating agencies, OJ L146, 31 May 2013

Directive 2010/73/EU of the European Parliament and of the Council of 24 November 2010 amending Directives 2003/71/EC on the prospectus to be published when securities are offered to the public or admitted to trading and 2004/109/EC on the harmonization of transparency requirements in relation to information about issuers whose securities are admitted to trading on a regulated market, OJ L327, 11 December 2010, p.1

Proposal for a Regulation of the European Parliament and of the Council on Insider Dealing and Market Manipulation (Market Abuse) of 20 October 2011, COM(2011) 651 final

Proposal for a Directive of the European Parliament and of the Council on Criminal Sanctions for Insider Dealing and Market Manipulation of 20 October 2011, COM(2011) 654 final

Proposal for a Directive of the European Parliament and of the Council amending Directive 2004/109/EC on the harmonization of transparency requirements in relation to information about issuers whose securities are admitted to trading on a regulated market and Commission Directive 2007/14/EC, 25 October 2011, COM(2011) 683/2

Proposal for a Directive of the European Parliament and of the Council on Markets in Financial Instruments repealing Directive 2004/39/EC of the European Parliament and of the Council, 20 October 2011, COM(2011) 656 final

Regulation (EU) No.236/2012 of the European Parliament and of the Council of 14 March 2012 on short selling and certain aspects of credit default swaps, OJ L86, 24 March 2012, p.1

Regulation (EU) No. 648/2012 of the European Parliament and of the Council of 4 July 2012 on OTC derivatives, central counterparties and trade repositories, OJ L201, 27 July 2012, p.1 